Annals of Warsaw University of Life Sciences - SGGW

Land Reclamation No 45 (1), 2013: 49-59

(Ann. Warsaw Univ. of Life Sci. - SGGW, Land Reclam. 45 (1), 2013)

\title{
Treatment of bath greywater using cartridge filters as a way to reduce water consumption in households
}

\author{
MACIEJ MALARSKI \\ Departament of Civil Engineering, Warsaw University of Life Sciences - SGGW
}

\begin{abstract}
Treatment of bath greywater using cartridge filters as a way to reduce water consumption in households. Nearly one third of the high quality water in households is used for flushing toilets. Water resources in Poland are relatively poor. Therefore the use of water of inferior quality parameters to flush the toilet bowls is satisfactory. It is possible to use for this purpose the greywater from the washing of the body (the bath water) after treating it to the level which doesn't threatens human life or health. The paper presents preliminary results of research on potential use of cartridge filter to treat greywater from the washing of the body (from bath) in order to re-use water in households. It was found not significant effect of increasing the quality of bath greywater treatment using polypropylene and carbon cartridge filters.
\end{abstract}

Key words: greywater, re-use of water, filtration, water quality, water consumption

\section{INTRODUCTION}

Water and access to it, is one of the basic conditions necessary for human life. The quantity and quality often affects the health and safety of the public. Water is bound up with the development of many branches of the economy (e.g. tourism or recreation). It has an impact on economic development as well as on the natural environment.

Taking into account the resources and method of use of water in Poland (Chudzicki and Sosnowski 2005; Chudzicki 2010; Kundzewicz et al. 2010) it can be concluded that the water is used carelessly. Usually, water used to flush toilets has drinking quality. It is obvious that for flushing toilet is not necessary to use water of such parameters.

A typical household in Poland uses on average about $125 \mathrm{dm}^{3}$ of water per person per day (Chudzicki and Sosnowski 2005; Chudzicki 2010). Half of it is used in the bath (about 26\%), body wash (10\%) and washing (about 15\%). At the same time in a typical household it is utilized on average about $38 \mathrm{dm}^{3}$ of water per person per day (about 30\%) to flush the toilet and about $8 \mathrm{dm}^{3}$ per person (about 6\%) for cleaning. Typically, used water has a very good quality (drinking water). Waste water generated during this process is called the greywater (waste water free of faeces), which can be used at least for flushing the toilet bowls. This will contribute to savings in water of drinking water quality.

However, it is necessary to remember that the greywater often contains soap, shampoo, washing powder, fats of human origin as well as different solids. These ingredients may cause a reluctance to use such greywater, even in the toilets. In addition, such water cause excessive deposition of contaminants on the surface of ceramic sanitary facilities. They can also result in the formation of aero- 
sols during flushing the toilet what is not always safe for human health. Therefore, before re-using the greywater should be treated to the level safe for human life and health, as well as minimize the deposition of contaminants. They should reduce the concentration of additives such as soap, shampoo, detergents, fats of human origin, dirt or hair.

In Poland there are no legal requirements for water used for flushing the toilet. It is only possible to determine, on the basis of the literature, the basic guidelines for the quality of the water. Such water should not be risk to one's life or health, it should not create flies habitat, it should not threaten the environment and it should have an aesthetic appearance (Mucha and Jodłowski 2010). In addition, installation of water supply to the toilets should not be uncomfortable for the environment, and its operation should be easy and friendly to the user.

The literature presents variety of innovative solutions using greywater in toilets without treatment (Mucha and Jodłowski 2010). However, such a greywater should be used immediately, without any retention in the toilet reservoir. Therefore, it is recommended that only properly treated greywater can be used to flush the toilet.

On the market one may find greywater treatment systems for re-use water commonly based on mesh polypropylene filters, sand filters and chlorine disinfection (Chrustowa-Boal et al. 1996; Jefferson et al. 1999; March et al. 2004; Guala et al. 2008; Godfrey et al. 2009). There are also biofilters using marsh vegetation (Czemiel 2000; Jenssen 2002; Ghisi and Ferreira 2007; Ghisi and Mengotti Oliveira 2007), as well as more special- ized devices such as RBC reactors or membrane bioreactors (Surendran and Wheatley 1998; Jefferson et al. 1999; Nolde 1999; Friedler et al. 2005; Friedler and Hadari 2006).

Such devices are installed in buildings for collective use, multi-family residential buildings and houses in the settlements. They are characterized by a fairly large volume and high price, which limits opportunity to easily and cheap install in a single household. They can be used in places of collective use, or multi- and single-family buildings with central greywater treatment to flush the toilets (installation takes place during the construction of buildings).

Re-used of water can bring savings of $30-50 \%$. Any reduction in water consumption (especially drinking water) can bring benefits to both present and future generations.

\section{MATERIAL AND METHODS}

\section{Research methodology}

This paper presents results of bath greywater treatment using polypropylene and carbon cartridge filters. These devices are relatively small. Standard height of cartridge is $254 \mathrm{~mm}$ (10") with diameter about $63 \mathrm{~mm}(2.5$ "). Replacing the cartridge is relatively simple, so one can do it without any specialized service. According to the manufacturers, the exchange of cartridge should be followed every 6 months in case of drinking water treatment. In the case of greywater filtration, durability is not assessed.

The analyzed greywater contained pollution from everyday body hygiene (using soap, shampoo etc.). Research on 
feasibility of housing cartridge filters for using them in greywater treatment were performed on a purposely built test stand (Fig. 1). Greywater stored in the averaging tank (1) was pumped by a centrifugal pump for sewage (2) to a housing cartridge filter (3). Fittings $(4,5,6)$ mounted in the system were used to adjust and determine the volume of greywater flow through the filter.
The ranges of the analyzed indicators of pollutants in the treated greywater using cartridge filters are shown in Table 1.

Polypropylene string filter cartridge of pore size 10 and $5 \mu \mathrm{m}$ and cartridge with activated carbon from coconut shells and KDF were tested. Therefore, the study was divided into three test series:

- series I - research on polypropylene string filter cartridge of pore size $10 \mu \mathrm{m}$,

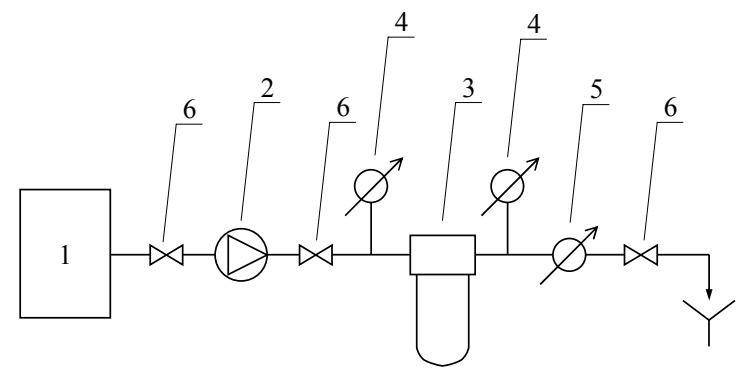

FIGURE 1. The scheme of bath greywater system filtration: 1 - raw greywater tank, 2 - delivery pump for greywater, 3 - cartridge filter with different, replaceable filter elements, 4 - pressure gauges for liquids at the inlet and outlet of the cartridge filter, 5 - water meter, 6 - control valves

During the tests, samples were taken from the greywater tank, and below the filter. Water sampling and analyzes were carried out for the following parameters: $\mathrm{pH}$ (PN/C 04540-01), total suspended solids - TSS, fixed suspended solids - FSS, volatile suspended solids - VSS (PN-EN 827:2005), total dissolved solids - TDS, total fixed solids - TFS, total volatile solids - TVS (PN-78 / C-04541), turbidity (ISO $7027 \mathrm{HACH}$ ), color (ISO $1670 \mathrm{HACH}$ ), total phosphorus, total nitrogen (violet $\mathrm{HACH}$ test method), BOD5 (Oxi Top Control), nitrites, nitrates, ammonia nitrogen (HACH colorimetric method), COD (PN ISO 15705), decay indicator (PN-76/C-04626), hardness (PN ISO 6059), alkalinity (ISO-9963-1).
- series II - research on polypropylene string filter cartridge of pore size $5 \mu \mathrm{m}$,

- series III - research on filter cartridge with activated carbon from coconut shells and KDF.

During the research samples were taken for the above-listed analytical tests. The results are shown in Tables 2-4 (each series of measurements separately).

\section{RESULTS AND DISCUSSION}

The composition and concentration of bath greywater depends mainly on how dirty is a person taking bath, the amount of used detergent and the amount of used water for flushing. Therefore, the 
TABLE 1. Ranges of values of selected indicators of pollutants in bath greywater testing

\begin{tabular}{|c|c|c|c|}
\hline Indicator & Unit & Values & Average \\
\hline Color - apparent & $\mathrm{mg} \mathrm{Pt} / \mathrm{l}$ & $233-320$ & 270 \\
\hline Color - after the hard filter disk & $\mathrm{mg} \mathrm{Pt} / 1$ & $33-122$ & 72 \\
\hline Turbidity & NTU & $21-46$ & 32 \\
\hline $\mathrm{pH}$ & - & $7.4-7.8$ & 7.6 \\
\hline Electrical conductivity - EC & $\mu \mathrm{s} / \mathrm{cm}$ & $1,230-1,430$ & 1,243 \\
\hline Decay & $\mathrm{h}$ & 170 & 170 \\
\hline Alkalinity & $\mathrm{mval} / \mathrm{l}$ & 7 & 7 \\
\hline Hardness & $\mathrm{mg} \mathrm{CaCO}_{3} / 1$ & 113-289 & 201 \\
\hline COD & $\mathrm{mg} \mathrm{O}_{2} / 1$ & $80-200$ & 100 \\
\hline BOD5 & $\mathrm{mg} \mathrm{O}_{2} / 1$ & $18-80$ & 51 \\
\hline Total suspended solids - TSS & $\mathrm{mg} / \mathrm{l}$ & $74-892$ & 466 \\
\hline Fixed suspended solids - FSS & $\mathrm{mg} / \mathrm{l}$ & $40-60$ & 52 \\
\hline Volatile suspended solids - VSS & $\mathrm{mg} / 1$ & $20-840$ & 414 \\
\hline Total dissolved solids - TDS & $\mathrm{mg} / \mathrm{l}$ & $750-1,070$ & 960 \\
\hline Total fixed solids - TFS & $\mathrm{mg} / \mathrm{l}$ & $310-700$ & 509 \\
\hline Total volatile solids - TVS & $\mathrm{mg} / \mathrm{l}$ & $360-540$ & 451 \\
\hline Nog & $\mathrm{mg} \mathrm{N} / 1$ & $1-9$ & 6.4 \\
\hline $\mathrm{N}-\mathrm{NO}_{3}{ }^{-}$ & $\mathrm{mg} \mathrm{N}-\mathrm{NO}_{3}{ }^{-} / 1$ & $0-2.11$ & 0.96 \\
\hline $\mathrm{N}-\mathrm{NO}_{2}$ & $\mathrm{mg} \mathrm{N}-\mathrm{NO}_{2} / 1$ & $0-0.01$ & 0.004 \\
\hline $\mathrm{N}-\mathrm{NH}_{4}^{+}$ & 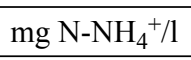 & $0.3-1.54$ & 0.8 \\
\hline Pog & $\mathrm{mg} \mathrm{P} / 1$ & $0-1.4$ & 0.75 \\
\hline
\end{tabular}

raw greywater have a high variability in the quality parameters (Table 1 ). In determining the effectiveness of different types of filter cartridges each time it was determined the composition of the raw greywater.

\section{Series I}

The results of the first series on the polypropylene string cartrige filter of filtration accuracy $10 \mu \mathrm{m}$ are shown in Table 2 . In the course of the test, an improvement of greywater quality parameters were done.

Made research were preliminary studies on the filtration of greywater from bath. Collected grey water in the aver- aging tank was treated on a filter. Complete clogging of the filter cartridge was not achieved to the volume of $80 \mathrm{dm}^{3}$ filtered. During the tests 5 samples were collected.

Filtered water are characterized by low concentrations of contaminants. As a result of filtration almost all indicators of quality have changed, except COD and electrical conductivity guidance for greywater salinity. For example, turbidity decreased to slightly exceed drinking water quality (Fig. 2).

Very important for the potential greywater user is decay indicator. For analyzed raw greywater samples it was on 
TABLE 2. Characteristics of bath greywater raw and treated on the housing cartridge filter with an filter accuracy of $10 \mu \mathrm{m}$ (inlet presure $0.83 \mathrm{bar}$ )

\begin{tabular}{|c|c|c|c|c|c|c|c|}
\hline \multirow{6}{*}{ Indicator } & \multirow{6}{*}{ Unit } & \multirow{6}{*}{$\begin{array}{l}\text { Raw } \\
\text { grey- } \\
\text { water }\end{array}$} & \multicolumn{5}{|c|}{ Average flow of filtrate $\left[\mathrm{dm}^{3} / \mathrm{s}\right]$} \\
\hline & & & \multicolumn{5}{|c|}{0.128} \\
\hline & & & \multicolumn{5}{|c|}{ Loss of pressure [bar] } \\
\hline & & & 0 & 0 & 0 & 0.02 & 0.07 \\
\hline & & & \multicolumn{5}{|c|}{ Volume of filtrate $\left[\mathrm{dm}^{3}\right]$} \\
\hline & & & 10 & 20 & 40 & 60 & 80 \\
\hline Color - apparent & $\mathrm{mg} \mathrm{Pt} / 1$ & 233 & 58 & 43 & 36 & 31 & 32 \\
\hline Color - after the hard filter disk & $\mathrm{mg} \mathrm{Pt} / 1$ & 39 & 36 & 38 & 33 & 30 & 25 \\
\hline Turbidity & NTU & 32.9 & 6.4 & 4.8 & 4.0 & 3.5 & 3.5 \\
\hline $\mathrm{pH}$ & - & 7.78 & 7.81 & 7.79 & 7.78 & 7.88 & 7.88 \\
\hline Electrical conductivity - EC & $\mu \mathrm{s} / \mathrm{cm}$ & 1,234 & 1,234 & 1,229 & 1,232 & 1,231 & 1,239 \\
\hline Decay & $\mathrm{h}$ & 170 & 360 & 360 & 360 & 360 & 360 \\
\hline COD & $\mathrm{mg} \mathrm{O}_{2} / 1$ & 125 & 110 & 120 & 125 & 100 & 100 \\
\hline BOD5 & $\mathrm{mg} \mathrm{O}_{2} / 1$ & 22.4 & 14.2 & 13 & 13.6 & 11.8 & 13 \\
\hline Total suspended solids - TSS & $\mathrm{mg} / \mathrm{l}$ & 74 & 20 & 16 & 8 & 138 & 64 \\
\hline Fixed suspended solids - FSS & $\mathrm{mg} / \mathrm{l}$ & 58 & 10 & 6 & 6 & 42 & 32 \\
\hline Volatile suspended solids - VSS & $\mathrm{mg} / \mathrm{l}$ & 16 & 10 & 10 & 2 & 96 & 32 \\
\hline Total dissolved solids - TDS & $\mathrm{mg} / \mathrm{l}$ & 1,066 & 794 & 855 & 857 & 806 & 851 \\
\hline Total fixed solids - TFS & $\mathrm{mg} / \mathrm{l}$ & 703 & 450 & 550 & 666 & 383 & 497 \\
\hline Total volatile solids - TVS & $\mathrm{mg} / \mathrm{l}$ & 363 & 344 & 305 & 191 & 423 & 354 \\
\hline Nog & $\mathrm{mg} \mathrm{N} / \mathrm{l}$ & 5 & - & 3 & - & - & - \\
\hline $\mathrm{N}-\mathrm{NO}_{3}{ }^{-}$ & $\mathrm{mg} \mathrm{N}-\mathrm{NO}_{3}{ }^{-} / 1$ & 0 & - & 0 & - & - & - \\
\hline $\mathrm{N}-\mathrm{NO}_{2}$ & $\mathrm{mg} \mathrm{N}-\mathrm{NO}_{2} / 1$ & 0.004 & - & 0.002 & - & - & - \\
\hline $\mathrm{N}-\mathrm{NH}_{4}{ }^{+}$ & $\mathrm{mg} \mathrm{N}^{-\mathrm{NH}_{4}}{ }^{+} / 1$ & 0.5 & - & 0.48 & - & - & - \\
\hline Pog & $\mathrm{mg} \mathrm{P} / 1$ & 0 & - & 0 & - & - & - \\
\hline
\end{tabular}

the level of 170 hours. It means that after about 3 days of sampling intense odour of decomposition of organic compounds in the greywater was perceptible. Filtering the water extended this time twice.

The content of organic compounds in the samples has improved (a reduction of about $50 \%$ ). In research there was not expected to achieve significant improvements with respect to nitrogen and phosphorus, which is confirmed by analytical studies.

\section{Series II}

Series II of research involved testing the greywater filtration on the polypropylene string filter cartridge of filtration accuracy $5 \mu \mathrm{m}$ (Table 3). As in Series I, raw greywater quality was analyzed in terms of the quality of the selected indicators. In this case, they were characterized by higher values of the concentrations of the individual components. It was found to be higher content of organic compounds expressed BOD5 index. Inspite of it 


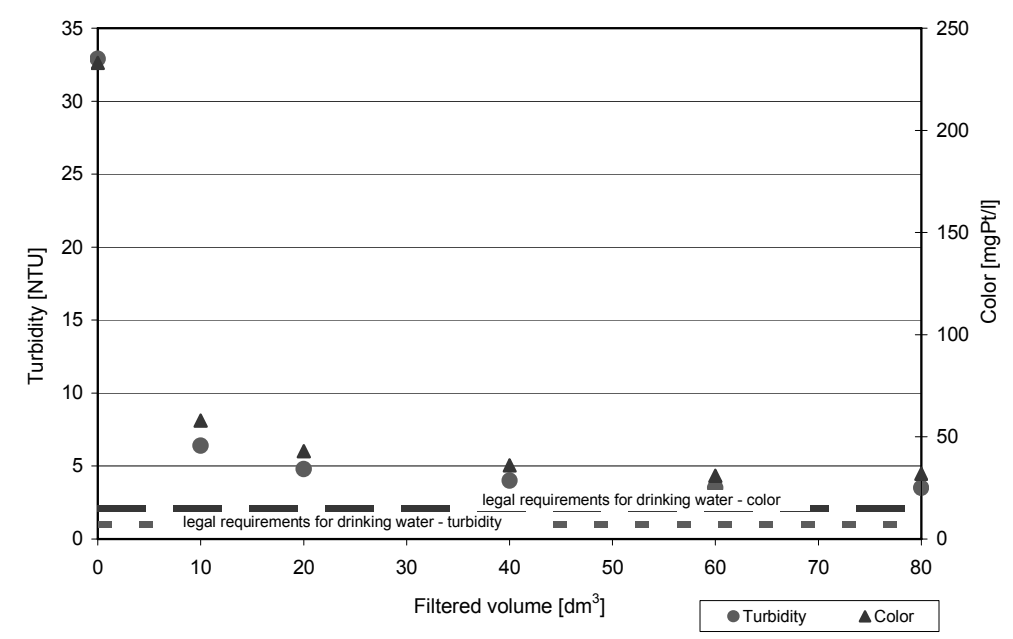

FIGURE 2. Effect of filtration duration on color and turbidity of greywater - series I

TABLE 3. Characteristics of bath greywater raw and treated on the housing cartridge filter with an filter accuracy of $5 \mu \mathrm{m}$ (inlet presure 0.83 bar)

\begin{tabular}{|c|c|c|c|c|c|c|c|c|c|c|}
\hline \multirow{6}{*}{ Indicator } & \multirow{6}{*}{ Unit } & \multirow{6}{*}{$\begin{array}{l}\text { Raw } \\
\text { grey- } \\
\text { water }\end{array}$} & \multicolumn{8}{|c|}{ Average flow of filtrate $\left[\mathrm{dm}^{3} / \mathrm{s}\right]$} \\
\hline & & & \multicolumn{8}{|c|}{0.134} \\
\hline & & & \multicolumn{8}{|c|}{ Loss of pressure [bar] } \\
\hline & & & 0 & 0 & 0.03 & 0.03 & 0.03 & 0.05 & 0.08 & 0.13 \\
\hline & & & \multicolumn{8}{|c|}{ Volume of filtrate $\left[\mathrm{dm}^{3}\right]$} \\
\hline & & & 10 & 20 & 30 & 50 & 70 & 100 & 118 & 124 \\
\hline Color - apparent & $\mathrm{mg} \mathrm{Pt} / 1$ & 320 & 292 & 281 & 264 & 251 & 263 & 254 & 251 & 246 \\
\hline $\begin{array}{l}\text { Color - after the } \\
\text { hard filter disk }\end{array}$ & $\mathrm{mg} \mathrm{Pt} / 1$ & 92 & 78 & 78 & 78 & 80 & 84 & 86 & 86 & 87 \\
\hline Turbidity & NTU & 40.6 & 35 & 33.3 & 31.4 & 31.3 & 30 & 30 & 29.9 & 28.8 \\
\hline $\mathrm{pH}$ & - & 7.57 & 7.55 & 7.56 & 7.53 & 7.52 & 7.49 & 7.5 & 7.11 & 7.52 \\
\hline $\begin{array}{l}\text { Electrical conduc- } \\
\text { tivity - EC }\end{array}$ & $\mu \mathrm{s} / \mathrm{cm}$ & 1,251 & 1,219 & 1,251 & 1,254 & 1,253 & 1,254 & 1,252 & 1,254 & 1,255 \\
\hline Decay & $\mathrm{h}$ & 170 & 170 & 170 & 170 & 170 & 170 & 170 & 170 & 170 \\
\hline COD & $\mathrm{mg} \mathrm{O}_{2} / 1$ & 93.5 & - & - & - & 93.5 & - & - & - & - \\
\hline BOD5 & $\mathrm{mg} \mathrm{O}_{2} / 1$ & 50.9 & 33 & 30 & 30 & 33 & 51 & 48 & 57 & 52 \\
\hline $\begin{array}{l}\text { Total suspended } \\
\text { solids - TSS }\end{array}$ & $\mathrm{mg} / \mathrm{l}$ & 432 & 484 & 444 & 528 & 384 & 66 & 156 & - & - \\
\hline $\begin{array}{l}\text { Fixed suspended } \\
\text { solids - FSS }\end{array}$ & $\mathrm{mg} / \mathrm{l}$ & 46 & 44 & 16 & 56 & 34 & 34 & 26 & - & - \\
\hline $\begin{array}{l}\text { Volatile suspended } \\
\text { solids - VSS }\end{array}$ & $\mathrm{mg} / \mathrm{l}$ & 386 & 44 & 428 & 472 & 350 & 32 & 130 & - & - \\
\hline Nog & $\mathrm{mg} \mathrm{N} / 1$ & 5 & - & - & - & 4.6 & - & - & - & - \\
\hline $\mathrm{N}-\mathrm{NH}_{4}^{+}$ & 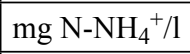 & 0.61 & 0.63 & - & - & 0.59 & - & - & - & - \\
\hline Pog & $\mathrm{mg} \mathrm{P} / 1$ & 0.1 & - & - & - & 0 & - & - & - & - \\
\hline
\end{tabular}


decay indicator for this water was also 170 hours.

Collected greywater in the averaging tank was treated on a filter. Complete clogging of the filter cartridge was not achieved to the volume of $124 \mathrm{dm}^{3}$ filtered. During the tests 8 samples were collected.

Also in this case there wasn't obtained a larger effect of reducing the content of organic pollutants expressed by BOD5. After the initial reduction in the concentration of about $35 \%$, efficiency dropped to zero (after filtering about $50 \mathrm{dm}^{3}$ of greywater).

Important for the potential greywater user are organoleptic indicators such as color and turbidity. Figure 3 shows that both indicators are reduced during tests. Trend lines are falling with volume of filtrate. This situation is associated with decreasing flow of greywater, with is caused by clogged pores of the filter cartridge.

\section{Series III}

In the third series of research the filter cartridge with activated carbon from coconut shells and KDF was tested. The research was conducted analogously to the previous series. As a result of research the parameters of the filter cartridge for the greywater quality parameters were analyzed (Table 4). Collected greywater in the averaging tank was treated on a filter. Complete clogging of the filter cartridge was not achieved to the volume of $88 \mathrm{dm}^{3}$ filtered. During the tests 6 samples were collected.

Filtered water are characterized by low concentrations of contaminants. As a result of filtration analyzed greywater quality parameters did not change significantly. Improvement was noticeable for such parameters as turbidity (11-21\%), COD $(25 \%)$, BOD5 (8-35\%), TSS (72$-95 \%)$. Decay indicator has not changed in spite of filtration and stood at 170 hours.

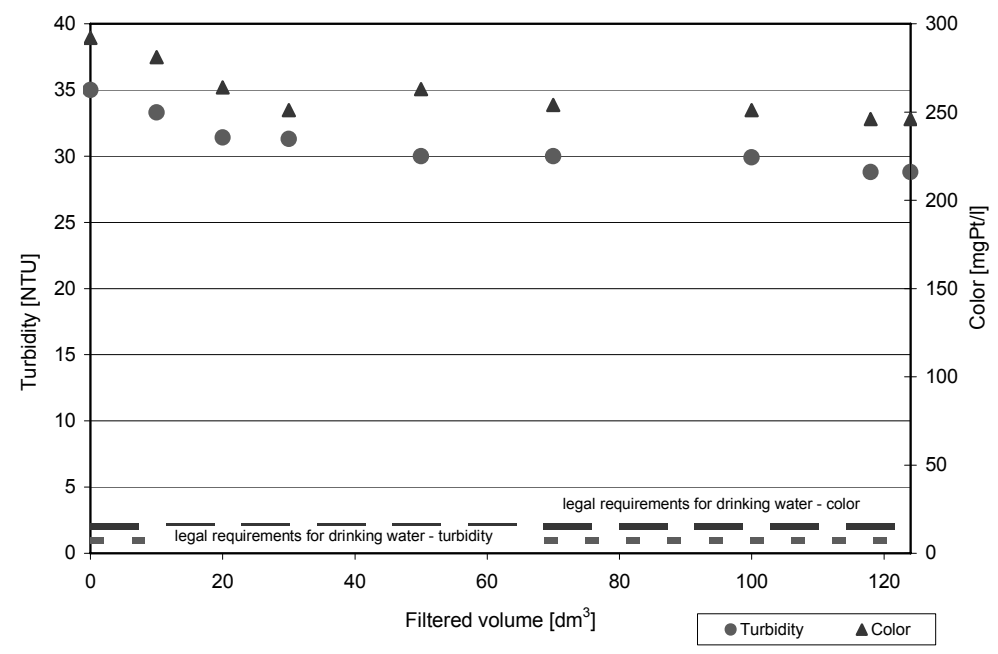

FIGURE 3. Effect of filtration duration on color and turbidity of greywater - series II 
TABLE 4. Characteristics of bath greywater raw and treated on the housing cartridge filter with activated carbon from coconut shells and KDF (inlet presure 0.83 bar)

\begin{tabular}{|c|c|c|c|c|c|c|c|c|}
\hline \multirow{6}{*}{ Indicator } & \multirow{6}{*}{ Unit } & \multirow{6}{*}{$\begin{array}{c}\text { Raw } \\
\text { grey } \\
\text { water }\end{array}$} & \multicolumn{6}{|c|}{ Average flow of filtrate $\left[\mathrm{dm}^{3} / \mathrm{s}\right]$} \\
\hline & & & \multicolumn{6}{|c|}{0.149} \\
\hline & & & \multicolumn{6}{|c|}{ Loss of pressure [bar] } \\
\hline & & & 0 & 0 & 0.06 & 0.15 & 0.23 & 0.43 \\
\hline & & & \multicolumn{6}{|c|}{ Volume of filtrate $\left[\mathrm{dm}^{3}\right]$} \\
\hline & & & 13 & 22 & 34 & 45 & 57 & 70 \\
\hline Color - apparent & $\mathrm{mgPt} / 1$ & 257 & 209 & 200 & 209 & 252 & 222 & 253 \\
\hline $\begin{array}{l}\text { Color - after the hard filter } \\
\text { disk }\end{array}$ & $\mathrm{mgPt} / \mathrm{l}$ & 122 & - & 130 & 149 & 126 & 156 & 113 \\
\hline Turbidity & NTU & 21.3 & 16.7 & 16.8 & 16.8 & 18.9 & 18.6 & 18.5 \\
\hline $\mathrm{pH}$ & - & 7.63 & 7.96 & 7.93 & 7.81 & 7.86 & 7.82 & 7.79 \\
\hline Electrical conductivity - EC & $\mu \mathrm{s} / \mathrm{cm}$ & 1,244 & 1,243 & 1,243 & 1,248 & 1,246 & 1,247 & 1,248 \\
\hline Decay & $\mathrm{h}$ & 170 & 170 & 170 & 170 & 170 & 170 & 170 \\
\hline COD & $\mathrm{mg} \mathrm{O}_{2} / 1$ & 80.8 & - & 60.6 & - & - & - & 60.6 \\
\hline BOD5 & $\mathrm{mg} \mathrm{O}_{2} / 1$ & 79.7 & 52.6 & 52 & 68.5 & 72.1 & 73.2 & 72.7 \\
\hline $\begin{array}{l}\text { Total suspended solids } \\
\text { - TSS } \\
\end{array}$ & $\mathrm{mg} / 1$ & 892 & - & 252 & 104 & 108 & 45 & 68 \\
\hline $\begin{array}{l}\text { Fixed suspended solids } \\
\text { - FSS }\end{array}$ & $\mathrm{mg} / \mathrm{l}$ & 52 & - & 76 & 84 & 16 & 44 & 52 \\
\hline $\begin{array}{l}\text { Volatile suspended solids } \\
\text { - VSS }\end{array}$ & $\mathrm{mg} / \mathrm{l}$ & 840 & - & 176 & 20 & 92 & 4 & 16 \\
\hline $\begin{array}{l}\text { Total dissolved solids } \\
\text { - TDS }\end{array}$ & $\mathrm{mg} / \mathrm{l}$ & 854 & 829 & 895 & 849 & 874 & 930 & 937 \\
\hline Total fixed solids - TFS & $\mathrm{mg} / \mathrm{l}$ & 315 & 461 & 581 & 433 & 415 & 564 & 496 \\
\hline Total volatile solids - TVS & $\mathrm{mg} / \mathrm{l}$ & 529 & 368 & 314 & 416 & 459 & 366 & 441 \\
\hline Nog & $\mathrm{mg} \mathrm{N} / 1$ & 5.1 & - & 3.9 & - & - & 4.2 & - \\
\hline $\mathrm{N}-\mathrm{NO}_{3}{ }^{-}$ & $\mathrm{mg} \mathrm{N}-\mathrm{NO}_{3}{ }^{-} / 1$ & 0 & - & 0 & - & - & 0 & - \\
\hline $\mathrm{N}-\mathrm{NO}_{2}$ & $\mathrm{mg} \mathrm{N}-\mathrm{NO}_{2} / 1$ & 0.004 & - & 0.003 & - & - & 0.004 & - \\
\hline $\mathrm{N}-\mathrm{NH}_{4}{ }^{+}$ & $\mathrm{mg} \mathrm{N}-\mathrm{NH}_{4}^{+} / 1$ & 1.54 & - & 1.2 & - & - & 1.46 & - \\
\hline Pog & $\mathrm{mg} \mathrm{P} / 1$ & 1.4 & - & 0.9 & - & - & 1.1 & - \\
\hline
\end{tabular}

Indicators such as color and turbidity firstly were reduced and after filtraction about $30 \mathrm{dm}^{3}$ greywater become almost on the original concentration (Fig. 4). Similar situation is with BOD5. After first reduction concentraction of BOD5 increased to the initial level. Sorption capacity of carbon cartridge quickly exhausted but it still was operating as a simple filter cartridge reducing the concentration indicators in the low range. Taking into account the rapid pressure drop of filtrate it is to be expected quickly complete clogging of the filter cartridge.

Only when the greywater is after treatment processes, it can be stored 


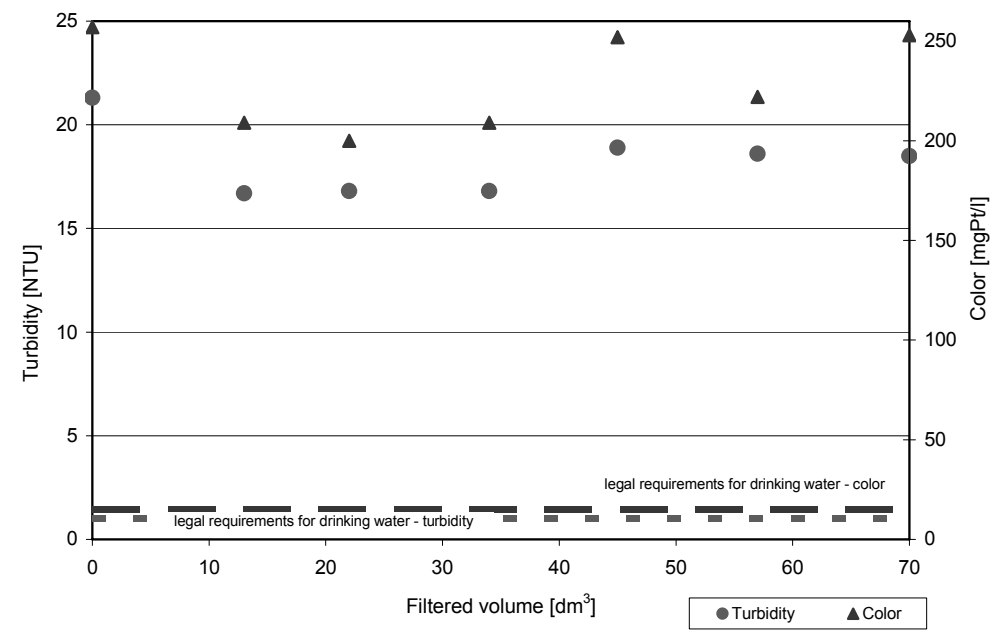

FIGURE 4. Effect of filtration duration on color and turbidity of greywater - series III

in tanks until it is used in an appropriate time. According to the definition of this type of water, it should not contain faecal bacteria. However, according to Jeppsen's research (1996) such situation happens quite often. Thus, for example, in Australia the use of greywater in toilet without treating is possible only when using the integrated sink with toilet tank (Jeppsen 1996).

The composition of greywater causes various difficulties related to its re-use. Flushing toilets may generated aerosols spreading bacteria and viruses (Jeppsen 1996). In the toilet tank, on the inlet valve and on the bell is the possibility of deposition of unwanted materials (Mucha and Jodłowski 2010). This may result in loss of tightness and uncontrolled flow of water from the tank into the toilet. Therefore, casual greywater treatment may be sufficient.

Biodegradation of organic substances results in the formation of odours and promotes the growth of microorganisms. In the literature (March et al. 2004; Gual et al. 2008), you can find recommendations for holding greywater in tanks with not longer than 48 hours. In the case of greywater from washing mashines it should be even less than 10 hours (Malarski 2012). The research gives similar results.

\section{CONCLUSIONS}

For the potential greywater user organoleptic indicators (color, turbidity, decay) are very important. These indicators point to user attitudes to greywater. So they have to be on satisfactory level, preferably close to the limit values for drinking water.

The analysis of greywater filtration results shows that using housing cartrige filters do not show a significant improvement in the quality of greywater. Therefore it is required a more accurate treatment of the device.

The full clogging of used filter cartridges was not achieved. Taking into account only a partial reduction of 
contamination indicators, this cartridges can be used for pre-treatment of bath greywater.

However, based on the results of measurement of pressure loss in the filter it can be stated that carbon filter cartridges have to be replaced frequently (probably after 2-4 baths). Such quantities virtually eliminate the practical use of carbon filter cartridges to technical installations as a pre-treatment of bath greywater, due to a very high costs of such system (frequent replacement of filter cartridges).

As can be seen from the research, greywater is biodegradable. In the analyzed samples the intensive smell was noticeable after about 3 days ( 72 hours).

Greywater treatment from a technical point of view is a difficult issue because of the change of water quality parameters. This water, before its re-use, requires proper preparation due to limitations of hygiene, health and environment. However, the application system using the greywater is preferred, especially in the context of reducing the demand for tap water. Any reduction in water consumption (especially drinking water) can bring benefits to both present and future generations.

\section{REFERENCES}

CHRISTOWA-BOAL D., EDEN R.E., McFARLANE S. 1996: An investigation into greywater reuse for urban residential properties. Desalination 106, 391-197.

CHUDZICKI J. 2010: Oszczędzanie wody bez rezygnacji $\mathrm{z}$ komfortu [Saving water without sacrificing comfort]. II debata Akademii Budowlanej Ładny Dom. http://ladnydom.p./budowa/
1,106580,6719177,Oszczedzanie wo dy_bez_rezygnacji_z komfortu+Druga.html [Accessed 2012.10.24].

CHUDZICKI J., SOSNOWSKI S. 2005: Instalacje wodociagowe. Projektowanie, wykonawstwo, eksploatacja [Water supply installations. The design, construction, operation]. Wydawnictwo SeidelPrzywecki, Warszawa.

CZEMIEL J. 2000: Phosphorus and nitrogen in sanitary systems in Kalmar. Urban Water 2, 63-69.

FRIEDLER E., HADARI M. 2006: Economic feasibility of on-site greywater reuse in multi-storey buildings. Desalination 190 , 221-234.

FRIEDLER E., KOVALIO R., GALIL N.I. 2005: On-site greywater treatment and reuse in multi-storey buildings. Water Science \& Technology 51, 187-194.

GHISI E., FERREIRAD.F. 2007: Potential for potable water savings by using rainwater and greywater in a multi-storey residential building in southern Brazil. Building and Environment 42, 2512-2522.

GHISI E., MENGOTTI DE OLIVEIRA S. 2007: Potential for potable water savings by combining the use of rainwater and greywater in houses in southern Brazil. Building and Environment 42, 1731-1742.

GODFREY S., LABHASETWAR P., WATE S. 2009: Greywater reuse in residential schools in Madhya Pradesh, India - A case study of cost-benefit analysis. Resources, Conservation and Recycling 53, 287-293.

GUAL M., MOIA A., MARCH J.G. 2008: Monitoring of an indoor pilot plant for osmosis rejection and greywater reuse to flush toilets in a hotel. Desalination 219, 81-88.

JEFFERSON B., LAINE A., PARSONS S., STEPHENSON T., JUDD S. 1999: Technologies for domestic wastewater recycling. Urban Water 1, 285-292.

JENSSEN P.D. 2002: Design and performance of ecological sanitation systems in Norway. EcoSanRes http://greywater- 
action.org/sites/default/files/laura/Sep09/ ecosan-norway-jenssen.pdf [Accessed 2013.10.20].

JEPPSEN B. 1996: Domestic greywater reuse: Australia's challenge for the future. Desalination 106, 311-315.

KUNDZEWICZ Z.W., ZALEWSKI M., KĘDZIORA A., PIERZGALSKI E. 2010: Zagrożenia związane $\mathrm{z}$ wodą [Water-related threats]. PAN Nauka 4, 87-96 [Engl. summ.].

MALARSKI M. 2012: Podczyszczanie wód szarych popralniczych na filtrach narurowych wkładkowych [Treatment of gray water from washing mashines on the housing cartridges filters]. Informacja Instal 9, 72-75 [Engl. summ.].

MARCH J.G., GUAL M., OROZCO F. 2004: Experiences on greywater re-use for toilet flushing in a hotel (Mallorca Island, Spain). Desalination 164, 241-247.

MUCHA J., JODŁOWSKI A. 2010: Ocena możliwości wykorzystania wody szarej [Evaluation of the possibility use of gray water]. Gaz, Woda i Technika Sanitarna 7-8, 24-27.

NOLDE E. 1999: Greywater reuse systems for toilet flushing in multi-storey buildings - over ten years experience in Berlin. Urban Water 1, 275-284.

SURENDRAN S., WHEATLEY A. 1998: Grey-water reclamation for non-potable re-use. Water and Environment Journal 12 (6), 406-413.
Streszczenie: Podczyszczanie wód szarych z mycia ciała na filtrach narurowych wkladkowych jako sposób zmniejszenia zużycia wody w gospodarstwach domowych. Blisko trzecia część wody o wysokich parametrach jakości trafiająca do gospodarstw domowych zużywana jest do spłukiwania misek ustepowych. Zasoby wodne w Polsce są stosunkowo ubogie, dlatego też wykorzystanie do spłukiwania misek ustępowych wody o gorszych parametrach jakości jest korzystne. Możliwe jest wykorzystanie do tego celu wód szarych z mycia ciała (ścieków z wanny) po uprzednim oczyszczeniu ich do poziomu niezagrażającemu życiu lub zdrowiu człowieka. W pracy przedstawiono wstępne wyniki badań nad możliwością wykorzystania filtrów narurowych wkładkowych do podczyszczania wód szarych pochodzących z mycia ciała (z wanny) w celu ich powtórnego wykorzystania w gospodarstwach domowych. $\mathrm{Na}$ ich podstawie stwierdzono niewielki efekt poprawy jakości wody szarej w procesie filtracji na filtrach narurowych wkładkowych.

Stowa kluczowe: ścieki szare, recyrkulacja wody, filtracja, jakość wody, zużycie wody

MS. received 28 June 2013

\author{
Author's address: \\ Katedra Inżynierii Budowlanej \\ Wydział Budownictwa i Inżynierii Środowiska \\ SGGW \\ ul. Nowoursynowska 159 \\ 02-776 Warszawa, Poland \\ e-mail:maciej_malarski@sggw.pl
}

